F. Reprod. Fert. (1969) 18, 209-220

\title{
CHEMICAL AND ULTRASTRUCTURAL CHANGES IN RAM SPERMATOZOA AFTER WASHING, COLD SHOCK AND FREEZING
}

\author{
P. J. QUINN, I. G. WHITE AND K. W. GLELAND \\ Departments of Veterinary Physiology and Histology and Embryology, \\ University of Sydney, N.S.W., Australia
}

(Received 4th March 1968)

\begin{abstract}
Summary. There was little or no loss of DNA or phospholipid from ram spermatozoa after washing three times with an equal volume of isotonic tris buffer. There was substantial loss of non-dialysable orcinoland biuret-reactive substances and also acid soluble phosphorus and phospholipids after cold-shocking and freezing ram spermatozoa. These components were also rendered more extractable with $10 \% \mathrm{NaCl}$ after cold treatment. DNA was lost from cold-shocked and frozen ram spermatozoa after incubation at $37^{\circ} \mathrm{C}$ for $6 \mathrm{hr}$ and the rate of degradation of DNA into dialysable components was initially higher in coldshocked or frozen spermatozoa.

Electron microscopy showed that cold shock and freezing caused profound changes in the appearance of the corrugated and terminal parts of the acrosome in the majority of spermatozoa but there were no apparent changes in the smooth region. There was considerable swelling of the acrosome with reduction in the density of the material contained within the acrosomal membranes. The effects were more pronounced in frozen than in cold-shocked spermatozoa.

In the middle pieces, changes occurred in the matrix of the mitochondria making up the mitochondrial sheath. The matrix in cold-shocked and frozen spermatozoa appeared lighter than in the controls and loss of protein from the middle piece was confirmed histochemically.
\end{abstract}

\section{INTRODUCTION}

When ejaculated ram or bull spermatozoa are suddenly cooled to about $0^{\circ} \mathrm{C}$ (i.e. cold-shocked) the cell membrane becomes more permeable, as judged by the proportion of cells staining with eosin or Congo red (Lasley, Easley \& McKenzie, 1942; Hancock, 1951). This is accompanied by an irreversible decrease in motility and metabolic activity, breakdown of ATP and loss of cations, cellular proteins and phospholipids (Mann \& Lutwak-Mann, 1955; Mayer, 1955; Blackshaw \& Salisbury, 1957; Blackshaw, 1958; Quinn \& White, 1966). Freezing ram or bull spermatozoa to $-79^{\circ} \mathrm{C}$ results in an even greater disruption of motility and metabolism (White, Blackshaw \& Emmens, 
1954) and loss of phospholipid and cations (Hartree \& Mann, 1959; Pickett \& Komarek, 1964; Quinn \& White, 1966). The only structural changes reported on cold shock are loosening and disintegration of the acrosome (Hancock, 1952; Iype, Abraham \& Bhargava, 1963).

The present experiments are concerned with determining the loss of certain components from ram spermatozoa after washing, sudden cooling to $0^{\circ} \mathrm{G}$ (cold shock) and to $-79^{\circ} \mathrm{C}$ (freezing). Electron microscopy of ram spermatozoa following cold treatment has also been undertaken to obtain more precise information on the nature of any ultrastructural damage.

\section{MATERIAL AND METHODS}

\section{Semen}

Ram semen was obtained by electrical ejaculation by the method of Blackshaw (1954) and was maintained at $20^{\circ} \mathrm{G}$ during transfer to the laboratory. Only samples of good initial motility were used. Semen was cold-shocked by placing samples held at $30^{\circ} \mathrm{C}$ in 15-ml centrifuge tubes into an ice-water bath, and freezing in finely crushed solid $\mathrm{CO}_{2}$. After $10 \mathrm{~min}$ all samples were brought to $37^{\circ} \mathrm{C}$ for $5 \mathrm{~min}$. The detrimental effect of the cold treatment was checked on nine ejaculates by staining the spermatozoa with Congo red-nigrosin (Quinn, Salamon \& White, 1968) and by scoring motility (Emmens, 1947). The mean percentage of unstained cells and their motility scores were: control $87 \%$, $3 \cdot 7$; cold-shocked $15 \%, 1 \cdot 1$; deep-frozen $1 \%, 0$.

\section{Chemical analysis}

Proteins were precipitated with ice cold trichloroacetic acid to give a final concentration of $10 \%(\mathrm{w} / \mathrm{v})$ and the precipitate washed with $5 \%(\mathrm{w} / \mathrm{v})$ TCA. The supernatants were pooled and total acid-soluble phosphorus determined by the method of Fiske \& Subba Row (1925). The precipitate was washed three times in $5 \%(\mathrm{w} / \mathrm{v}) \mathrm{NaGl}$ and extracted twice with ethanol, acetone, ethanol : ether $(3: 1, \mathrm{v} / \mathrm{v})$ and once with ether for lipid phosphorus estimation. Nucleic acid was extracted twice from the residue with $10 \%(\mathrm{w} / \mathrm{v}) \mathrm{NaCl}$ at $98^{\circ} \mathrm{C}$ for $30 \mathrm{~min}$ and precipitated from the extract with 2 vols of ethanol after standing for $24 \mathrm{hr}$ at $-15^{\circ} \mathrm{C}$. The nucleic acid was washed twice with cold $80 \%(\mathrm{v} / \mathrm{v})$ ethanol and dissolved in $10 \%(\mathrm{v} / \mathrm{v})$ perchloric acid. Deoxyribose was estimated by reaction with diphenylamine using Burton's (1956) method as modified by Giles \& Myers (1965). Orcinol-reactive material (expressed as glucose) was estimated by the method of Hewitt (1937) and biuret-reactive material (expressed as bovine serum albumin) by the method of Wales, Scott \& White (1961).

\section{Electronmicroscopy}

Semen samples were fixed on small circles of Millipore filter, contained in a perspex holder, which were in contact with Palade's fixative below (and with $\mathrm{OsO}_{4}$ vapour above). This method of fixation resulted in coherent pellets convenient for embedding. The spermatozoa were less damaged by this method than by fixation in free suspension.

After dehydration in acetone, embedding in Araldite, sectioning and 
staining with uranyl acetate, the material was examined with an Hitachi HS7 electron microscope.

\section{Histochemistry}

Histochemical estimates of the DNA content of the sperm head and of the protein concentration in the middle piece were performed by two-wavelength microspectrophotometry, using the instrument described by Cleland (1965). The whole sperm head, stained by the Feulgen procedure after methanol fixation, was contained within the field-limiting aperture in DNA determinations. Methanol-fixed, methanol-chloroform extracted smears were stained with $1 \%$ Orange II in $0.01 \mathrm{~N}-\mathrm{HCl}$ for $30 \mathrm{~min}$, washed thoroughly in $0.01 \mathrm{~N}-\mathrm{HCl}$, blotted, dehydrated in absolute dioxan, and mounted in a medium of the same refractive index as the stained middle piece. This staining procedure has been shown to provide an adequate index of the protein (free amino group) content of histological objects. In the microspectrophotometric estimates of protein the proximal tenth of the middle piece was included in the field-limiting diaphragm. The calculated stain contents provide an index of the amount of protein per unit length in this region of the middle piece.

\section{Statistical methods}

The statistical significance of the results has been assessed by analyses of variance (Tables 1,2 and 4 ) or by $t$-tests (Table 3 ).

\section{RESULTS}

Effect of washing

The first experiment was a preliminary one to determine what effect the washing procedure to be used in subsequent experiments had on the chemical composition of spermatozoa.

TABLE 1

THE EFFEGT OF WASHING ON GERTAIN COMPONENTS OF RAM SPERMATOZOA

\begin{tabular}{c|c|c|c|c}
\hline $\begin{array}{c}\text { No. of } \\
\text { washings }\end{array}$ & $\begin{array}{c}D \mathcal{N A} \\
\left(\mathrm{mg} / 10^{9} \text { cells }\right)\end{array}$ & $\begin{array}{c}\text { Acid-soluble } \\
\text { phosphorus } \\
\left(\mu g / 10^{9} \text { cells }\right)\end{array}$ & $\begin{array}{c}\text { Lipid } \\
\text { phosphorus } \\
\left(\mu g / 10^{9} \text { cells }\right)\end{array}$ & $\begin{array}{c}\text { Residual } \\
\text { biuret-reactive } \\
\text { material } \\
\left(\mathrm{mg} / 10^{9} \text { cells }\right)\end{array}$ \\
\hline 0 & $3 \cdot 37$ & $1.52^{*}$ & 77 & $21 \cdot 6^{*}$ \\
1 & $3 \cdot 11$ & 225 & 77 & 6.45 \\
2 & $3 \cdot 23$ & $151^{\mathrm{b}}$ & 82 & $5 \cdot 88$ \\
3 & $3 \cdot 15$ & 157 & 78 & $5 \cdot 79$ \\
\hline
\end{tabular}

Mean values are given for three replicates.

* Values are for whole semen $(\mathrm{mg} / \mathrm{ml})$.

b, Significantly different from once washed spermatozoa $(P<0.01)$.

Ram semen was diluted with an equal volume of $0.9 \% \mathrm{NaCl}$, buffered with $50 \mathrm{~mm}$ Tris $(\mathrm{pH} 7)$. After $15 \mathrm{~min}$ at $30^{\circ} \mathrm{C}$ it was centrifuged $(2000 \mathrm{~g})$ at $15^{\circ} \mathrm{C}$ for $15 \mathrm{~min}$ and the supernatant removed and replaced by an equal volume of 
diluent. After $15 \mathrm{~min}$ at $30^{\circ} \mathrm{C}$, the supernatant was again removed and the washing procedure repeated twice more.

Table 1 shows that washing caused a marked loss of acid-soluble phosphorus from the spermatozoa. There was, however, no significant loss of DNA, phospholipid or residual biuret-reactive material (i.e. biuret-reactive material in the TGA precipitate after extraction with lipid solvents and $10 \% \mathrm{NaCl}$ ).

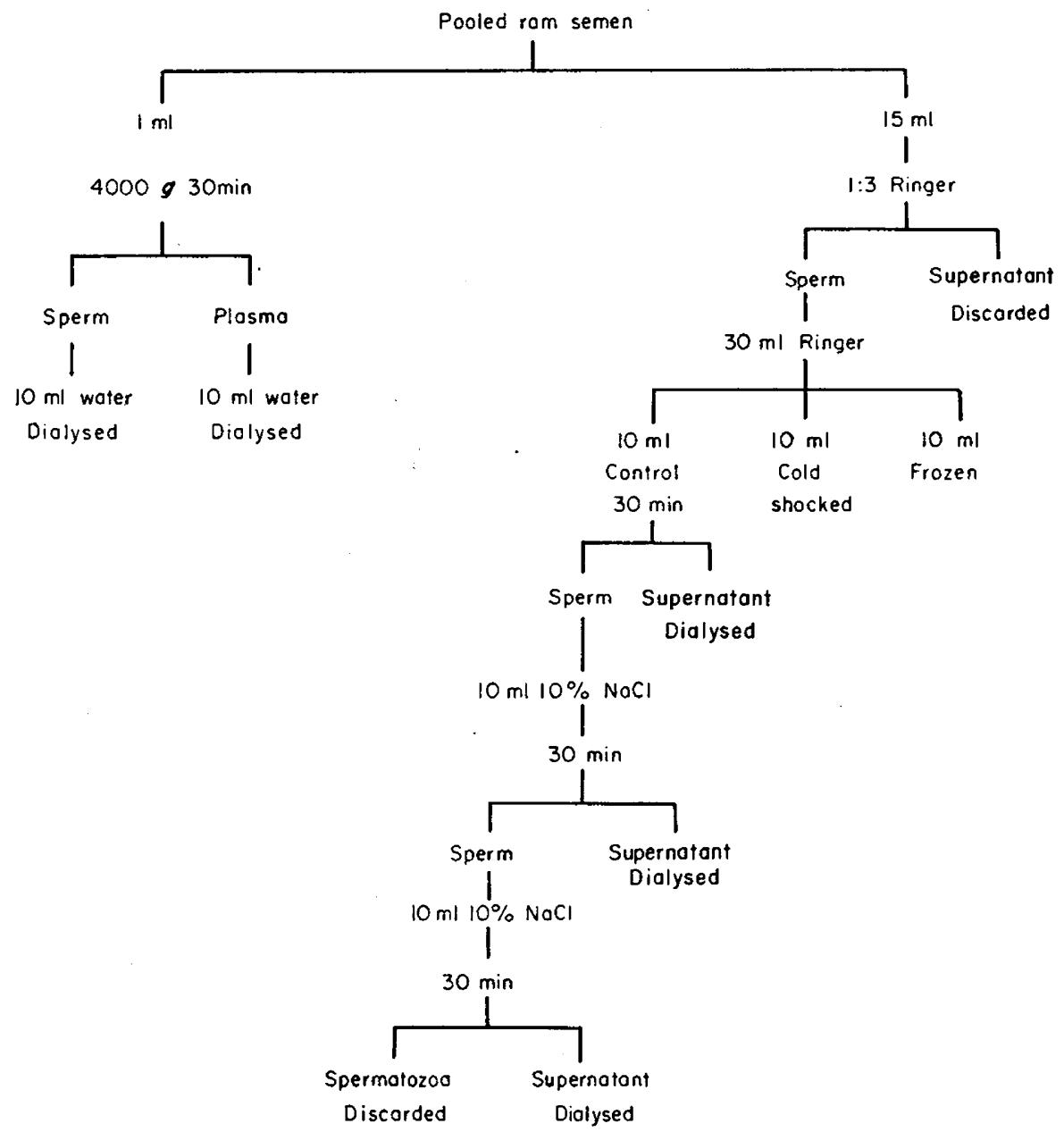

TExT-FIG. 1. Flow sheet for Experiment 2. The 10-ml suspensions of cold-shocked and frozen spermatozoa were each treated in the same way as the control.

Effect of cold shock and deep-freezing

Chemical analyses. The experiment was designed to determine the loss of substances of high molecular weight from spermatozoa on cold shock and freezing and to determine the extent to which these substances were rendered extractable in $10 \% \mathrm{NaCl}$.

Sixteen $\mathrm{ml}$ of pooled ram semen was obtained (Text-fig. l) and the spermatozoa and seminal plasma in a $1.0 \mathrm{ml}$ aliquot separated by centrifugation 
(Quinn, White \& Wirrick, 1965). Each fraction was mixed with $10 \mathrm{ml}$ of water and dialysed for $24 \mathrm{hr}$ against distilled water at $0^{\circ} \mathrm{C}$. The remaining $15 \mathrm{ml}$ of semen was diluted in $50 \mathrm{ml}$ of calcium-free Krebs-Ringer phosphate buffer (Umbreit, Burris \& Stauffer, 1959) and centrifuged $(3000 \mathrm{~g}$ ) for $15 \mathrm{~min}$ at $15^{\circ} \mathrm{C}$. The supernatant was discarded and the spermatozoa resuspended to $30 \mathrm{ml}$ in the same buffer and divided into three aliquots of $10 \mathrm{ml}$. One sample was held at $30^{\circ} \mathrm{C}$ (control), the second was cold-shocked and the third frozen. After thawing, all samples were incubated for a further $30 \mathrm{~min}$ and then cen-

TABLE 2

LOSS OF NON-DIALYSABLE COMPONENTS FROM COLD-SHOCKED AND FROZEN RAM SPERMATOZOA

\begin{tabular}{|c|c|c|c|c|c|c|}
\hline \multirow{2}{*}{ Treatment } & \multicolumn{3}{|c|}{$\begin{array}{l}\text { Orcinol-reactive material } \\
\left(\mu \mathrm{g} / 10^{8} \text { cells }\right)\end{array}$} & \multicolumn{3}{|c|}{$\begin{array}{c}\text { Biuret-reactive material } \\
\left(\mu \mathrm{g} / 10^{8} \text { cells }\right)\end{array}$} \\
\hline & $\begin{array}{c}\text { Before } \\
10 \% \text { NaCl } \\
\text { extraction }\end{array}$ & $\begin{array}{c}\text { In first } \\
10 \% \text { NaCl } \\
\text { extract }\end{array}$ & $\begin{array}{l}\text { In second } \\
10 \% \mathrm{NaCl} \\
\text { extract }\end{array}$ & $\begin{array}{c}\text { Before } \\
10 \% \mathrm{NaCl} \\
\text { extraction }\end{array}$ & $\mid \begin{array}{c}\text { In first } \\
10 \% \mathrm{NaCl} \\
\text { extract }\end{array}$ & $\begin{array}{c}\text { In second } \\
10 \% \mathrm{NaCl} \\
\text { extract }\end{array}$ \\
\hline $\begin{array}{l}\text { Control } \\
\text { Cold-shocked } \\
\text { Deep-frozen }\end{array}$ & $\begin{array}{l}10 \cdot 8 \\
19 \cdot 8 \\
22 \cdot 8\end{array}$ & $\begin{array}{r}7.9 \\
12.5 \\
13.7\end{array}$ & $\begin{array}{l}4 \cdot 5 \\
4 \cdot 6 \\
5 \cdot 9\end{array}$ & $\begin{array}{l}19 \cdot 3 \\
308 \\
409\end{array}$ & $\begin{array}{l}154 \\
236 \\
326\end{array}$ & $\begin{array}{r}92 \\
112 \\
127\end{array}$ \\
\hline
\end{tabular}

Mean values are given for three replicates. After dialysis, untreated spermatozoa contained $165 \mu \mathrm{g}$ of orcinol-reactive and $1815 \mu \mathrm{g}$ of biuret-reactive material per $10^{8}$ cells.

SUMMARY OF ANALYSIS OF VARIANCE

\begin{tabular}{l|c|c|c}
\hline \multicolumn{1}{c|}{ Source of variation } & & \multicolumn{2}{c}{ Variance ratio } \\
\cline { 2 - 4 } & d.f. & Orcinol & Biuret \\
\hline Between treatments (T) & & $19 \cdot 3^{\mathrm{b}}$ & $8 \cdot 7^{\mathrm{b}}$ \\
Between extractions in $10 \% \mathrm{NaCl}(\mathrm{E})$ & 2 & $73 \cdot 8^{\mathrm{b}}$ & $16 \cdot 8^{\mathrm{b}}$ \\
T/E interaction & 4 & $5 \cdot 0$ & $0 \cdot 3$ \\
Between replicates & 2 & $5 \cdot 4^{\mathrm{a}}$ & $7 \cdot 2^{\mathrm{b}}$ \\
Residual mean square & 16 & 502 & 5148 \\
\hline
\end{tabular}

a, $P<0.05 ; \mathrm{b}, P<0.01$.

trifuged for $15 \mathrm{~min}$ at $4000 \mathrm{~g}$. The supernatant was removed and the spermatozoa resuspended to $10 \mathrm{ml}$ in $10 \%(\mathrm{w} / \mathrm{v}) \mathrm{NaCl}$ and incubated for $30 \mathrm{~min}$ at $30^{\circ} \mathrm{G}$.

The supernatant was again removed and the washing and incubation procedure repeated. The first supernatant and two washing supernatants were then dialysed and orcinol-reactive and biuret-reactive material, and total phosphorus estimated in the contents of the dialysis sac.

There was a substantial loss of non-dialysable orcinol- and biuret-reactive substances to the surrounding medium after cold shock of washed ram spermatozoa (Table 2). Even more of these substances was usually lost after freezing, the loss amounting to 15 to $20 \%$ of the orcinol- and biuret-reactive material initially present in the spermatozoa. The $10 \% \mathrm{NaCl}$ extracts of the spermatozoa 
also contained more non-dialysable orcinol- and biuret-reactive substances after cold shock and freezing. Almost half of the non-dialysable and soluble phosphorus in the spermatozoa was also removed by cold treatment and there was some loss of lipid phosphorus. Practically no deoxyribonucleic acid, however, was lost from cold-shocked or frozen ram spermatozoa and it also resisted extraction with $10 \% \mathrm{NaCl}$.

Electron microscopy. Undiluted ram semen $(1 \mathrm{ml})$ was examined before and after cold shock and freezing. Even in control preparations the plasma membrane of the sperm head anterior to the post-nuclear cap (pnc) was, more often than not, either detached from the underlying acrosome or was actually stripped away from it (pm in PI. 1, Figs. 1 and 2). It is presumed, but by no means proved, that this was an artefact. The plasma membrane was nearly always intact and adherent over the rest of the sperm surface although breaks were not infrequent in the neck region (see arrow in Pl. 1, Fig. 1). The membrane changes in the acrosomal region were much more pronounced in coldshocked and frozen spermatozoa.

The acrosome of the ram sperm may be divided into three parts: a posterior, thin, smooth region (as in Pl. 1, Figs. 1 to 4); an anterior, thicker region often showing a somewhat corrugated surface (as in Pl. 1, Figs. 1 to 4); and a terminal ridge-like part, containing a denser body, found only in the region near the apex of the sperm head ('at' in Pl. 1, Fig. 2).

Cold shock and freezing cause profound changes in the appearance of the corrugated and terminal parts of the acrosome in the majority of spermatozoa but no changes were normally observed in the smooth part. The changes usually observed are a considerable swelling of the acrosome with a reduction in the density of the material contained within the acrosomal membrane (am of Pl. 1, Figs. 5 and 6). The outer surface of the latter is irregular and frequently shows evidence of blebbing (bl in Pl. 1, Figs. 5 and 6). Occasionally the swelling of the acrosome is not very marked although there has clearly been a loss of acrosome contents (Pl. 1, Fig. 6). The acrosomal effects observed were more pronounced in frozen than in cold-shocked sperm.

It was nevertheless difficult to see how these particular effects of cold shock and freezing could cause the profound depression of sperm motility and metabolism previously reported (White, Blackshaw \& Emmens, 1954; Mann \& Lutwak-Mann, 1955; Blackshaw \& Salisbury, 1957), and special

\section{EXPLANATION OF PLATE 1}

Abbreviations: ac, corrugated part of acrosome; am, acrosomal membrane; as, smooth part of acrosome; at, terminal part of acrosome; bl, blebs of acrosomal membrane; pm, plasma membrane; pnc, post-nuclear cap. The scales on this plate represent 1 micron. Fics. 1 and 2. Sperm heads from normal control preparation. Note the three parts of the acrosome (as, ac and at) and the post-nuclear cap. The plasma membrane covering the acrosomal region in Fig. 1 is detached but intact while that in Fig. 2 is detached and disrupted. In Fig. 1 there is a break in the plasma membrane in the neck region (arrows). Figs. 3 and 4. Sperm heads from a cold-shocked (Fig. 3) and a frozen (Fig. 4) preparation. Note the swelling of the corrugated and terminal regions of the acrosome in both cases and the lightness of the contents within the acrosomal membrane. The smooth part of the acrosome is unaffected.

Fics. 5 and 6. Sperm heads from a cold-shocked preparation at higher magnification showing the swelling of the corrugated acrosome and the blebbing of the acrosomal membrane. 
PLATE 1

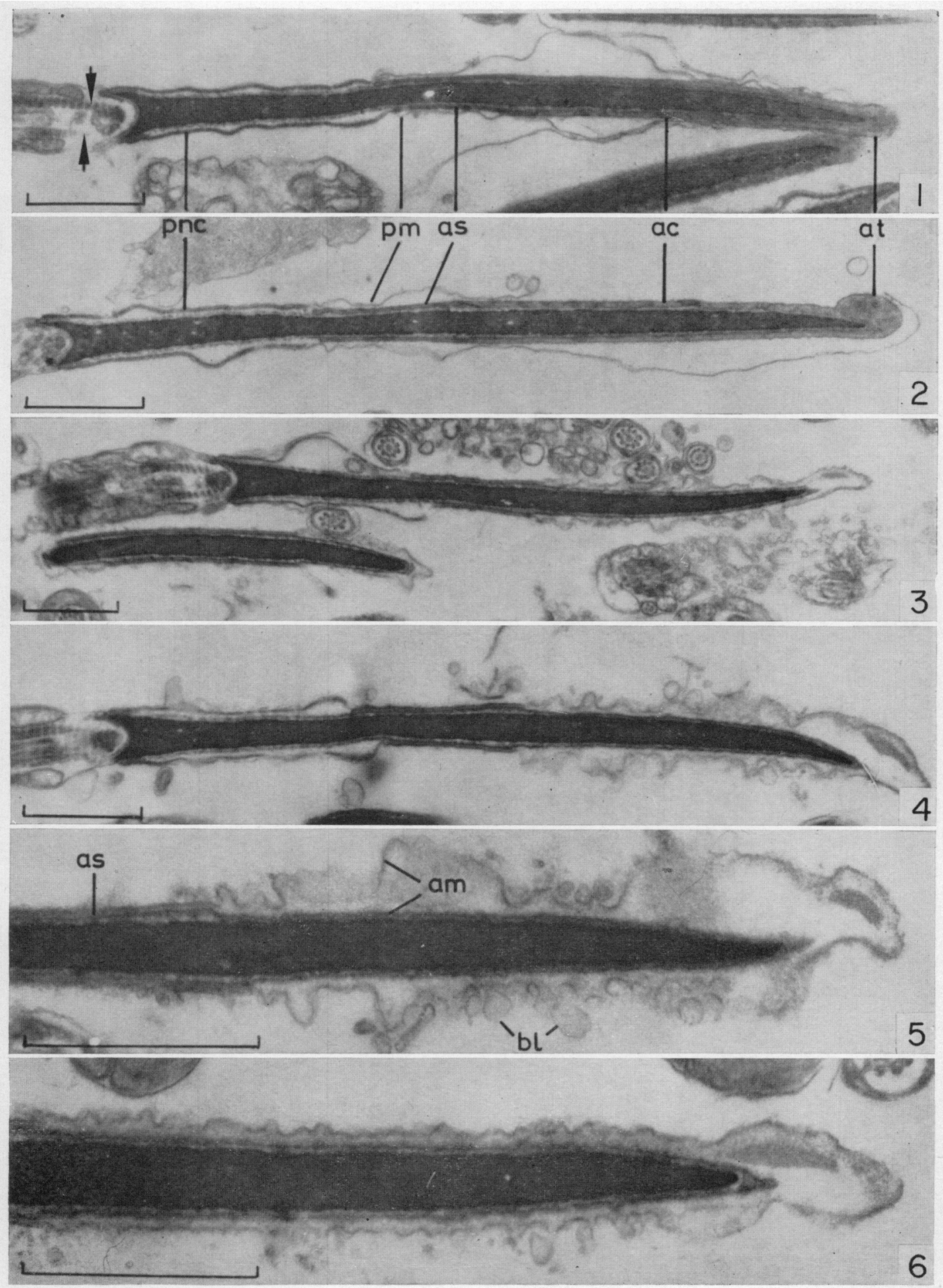

(Facing p. 214) 
PLATE 2
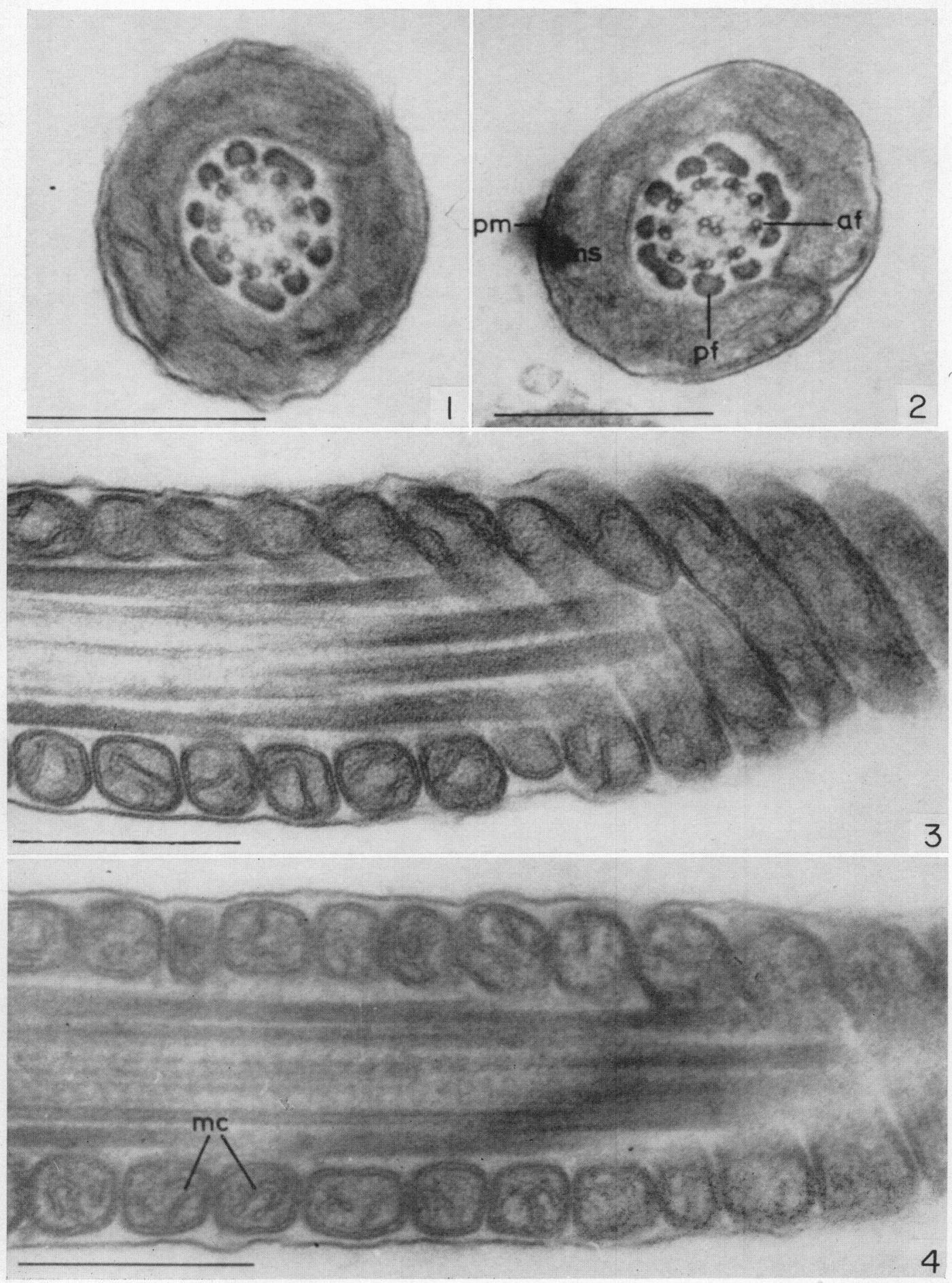

(Facing p. 215) 
attention was therefore paid to the motor apparatus (middle and principal pieces). No consistent differences, however, could be observed in the form, arrangement or apparent density of the filaments of the axial complex or of the peripheral fibrils of the middle piece and proximal main piece (see af and $\mathrm{pf}$ in Pl. 2, Figs. 1 to 4 ). In the latter, the plasma membrane and fibrous sheath appeared perfectly normal.

In the middle piece, changes which appeared to be constant occurred in the matrix of the mitochondria making up the mitochondrial sheath. The matrix in cold-shocked and frozen spermatozoa consistently appeared somewhat lighter than in the controls (Pl. 2, Figs. 1 to 4 ). No differences could be observed

TABLE 3

EFFECT OF VARIOUS TREATMENTS ON THE PROTEIN CONTENT OF THE MIDDLE PIECE DETERMINED HISTOCHEMIGALLY

\begin{tabular}{l|c|c|c}
\hline \multicolumn{1}{c|}{ Treatment } & Whole semen & $\begin{array}{c}\text { Washed } \\
\text { spermatozoa }\end{array}$ & $\begin{array}{c}10 \% \mathrm{NaCl} \\
\text { extraction }\end{array}$ \\
\cline { 2 - 3 } Control & $164 \pm 5 \cdot 8(39)$ & $138 \pm 3 \cdot 0(18)$ & $112 \pm 4 \cdot 3(20)$ \\
Cold-shocked & $140 \pm 3 \cdot 2(77)^{\mathrm{b}}$ & $115 \pm 3 \cdot 8(39)^{\mathrm{b}}$ & $106 \pm 3 \cdot 7(40)$ \\
Frozen & $136 \pm 2 \cdot 8(20)^{\mathrm{b}}$ & $80 \pm 2 \cdot 2(40)^{\mathrm{b}}$ & $68 \pm 3 \cdot 4(40)^{\mathrm{b}}$ \\
\hline
\end{tabular}

b, $P<0.01$. Significantly different from control.

Figures are the mean protein content of the proximal part of the middle piece in arbitrary units followed by the standard error; in parentheses the number of spermatozoa on which the mean is based.

in the plasma membrane covering the middle piece or in the morphology of the mitochondrial crests between control and cold-shocked or frozen spermatozoa (pm and $\mathrm{mc}$ in Pl. 2, Figs. 1 to 4 ).

Histochemistry. Because of the uncertainties in interpretation of small density differences apparent in electron micrographs made from sections of unknown thickness, confirmation of the findings reported above was sought by looking for a loss of protein from the middle piece.

Three sets of material were examined:

(a) whole semen: (i) maintained at room temperature; (ii) cold-shocked; (iii) frozen.

(b) Ringer-washed spermatozoa treated as in (a); see section on chemical analysis and Text-fig. 1 .

(c) Ringer-washed spermatozoa treated as in (a) but subsequently extracted with $10 \% \mathrm{NaCl}$; see section on chemical analysis and Text-fig. 1 .

\section{EXPLANATION OF PLATE 2}

Abbreviations: af, axial filaments; mc, mitochondrial crests; ms, mitochondrial sheath of middle piece; pf, peripheral fibrils; pm, plasma membrane. The scales on this plate represent half a micron.

Figs. 1 and 3. Middle pieces in cross section (Fig. 1) and oblique section (Fig. 3) from normal control preparations.

Fics. 2 and 4. Middle pieces in cross and oblique section from a cold-shocked preparation. In comparing the two preparations, note the integrity of the axial filaments and peripheral fibrils and the apparent lightening of the matrix in the mitochondria of the mitochondrial sheath. No changes in the plasma membrane or mitochondrial crests are evident. 
The results are shown in Table 3. It is clear that there was indeed a loss of protein from the middle piece associated with cold-shocking and freezing in either seminal plasma or saline.

Washing the spermatozoa potentiated the protein loss in frozen although not in cold-shocked spermatozoa. The apparent loss of protein caused by washing in Ringer must be interpreted with caution. It is conceivable that an accumulation of seminal plasma protein may occur in the immediate vicinity of the middle pieces during drying of the smears. This would cause an increase in the protein values observed by the histophotometric techniques employed.

No differences in DNA content of the sperm head referable to the treatment could be detected in any of the samples examined.

\section{Effect of prolonged incubation after cold shock and freezing on sperm $D \mathcal{N} A$}

Since the spermatozoa in the previous study had only been incubated for 30 min after cold treatment a further experiment was undertaken in which $1 \mathrm{ml}$ of

\section{TABLE 4}

THE EFFECT OF COLD SHOCK AND FREEZING ON THE DNA CONTENT OF RAM SPERMATOZOA

\begin{tabular}{c|l|c}
\hline \multicolumn{1}{c|}{ Experiment } & \multicolumn{1}{c|}{ Treatment } & $\begin{array}{c}D \mathcal{N} A \\
\left(\mathrm{mg} / 10^{9} \text { cells }\right)\end{array}$ \\
\hline 1 (three replicates) & Unwashed control & $3 \cdot 18$ \\
& Unwashed cold-shocked & $2 \cdot 97$ \\
2 (nine replicates) & Unwashed frozen & $2 \cdot 44^{\mathrm{b}}$ \\
& Unwashed control & $3 \cdot 29$ \\
& Washed control & $3 \cdot 26$ \\
& Washed cold-shocked & $2 \cdot 59^{\mathrm{b}}$ \\
& Washed frozen & $2 \cdot 44^{\mathrm{b}}$ \\
\hline
\end{tabular}

b, $P<0.01$ Significantly different from unwashed control in Exp. 1 and washed control in Exp. 2.

ram semen was incubated for $6 \mathrm{hr}$ at $37^{\circ} \mathrm{G}$ after cold shock and freezing. The DNA content was then determined and Table 4 shows a significant loss from the spermatozoa after freezing. Analyses were also made of spermatozoa washed once in $5 \mathrm{vol}$ of calcium-free Krebs-Ringer phosphate after the semen had been cold-shocked and incubated for $6 \mathrm{hr}$. The DNA content of the washed spermatozoa after cold shock and freezing was significantly less than the unwashed control. Washing, itself, clearly had no effect.

The next experiment was designed to demonstrate the degradation of DNA into dialysable end-products. A 3-ml sample of pooled ram semen was divided into three equal aliquots and $0.5 \mathrm{mg}$ each of penicillin and streptomycin added. One aliquot was cold-shocked, another frozen and all three samples then placed in dialysis sacs and dialysed at $37^{\circ} \mathrm{C}$ against $5 \mathrm{ml}$ of a diluent consisting of $150 \mathrm{~mm} \mathrm{NaCl}, 3 \mathrm{~mm} \mathrm{MgCl}{ }_{2}, 50 \mathrm{~mm}$ tris- $\mathrm{HCl}$ buffer ( $\mathrm{pH} \mathrm{7.4)}$ and containing antibiotics. The medium outside the sac was removed each day for deoxyribose determination and replaced with fresh diluent. 
The loss of deoxyribose from cold-shocked and frozen ram spermatozoa during 10 days dialysis at $37^{\circ} \mathrm{G}$ is shown in Text-fig. 2. The rate of loss of deoxyribose during the first 4 days was higher in cold-shocked spermatozoa

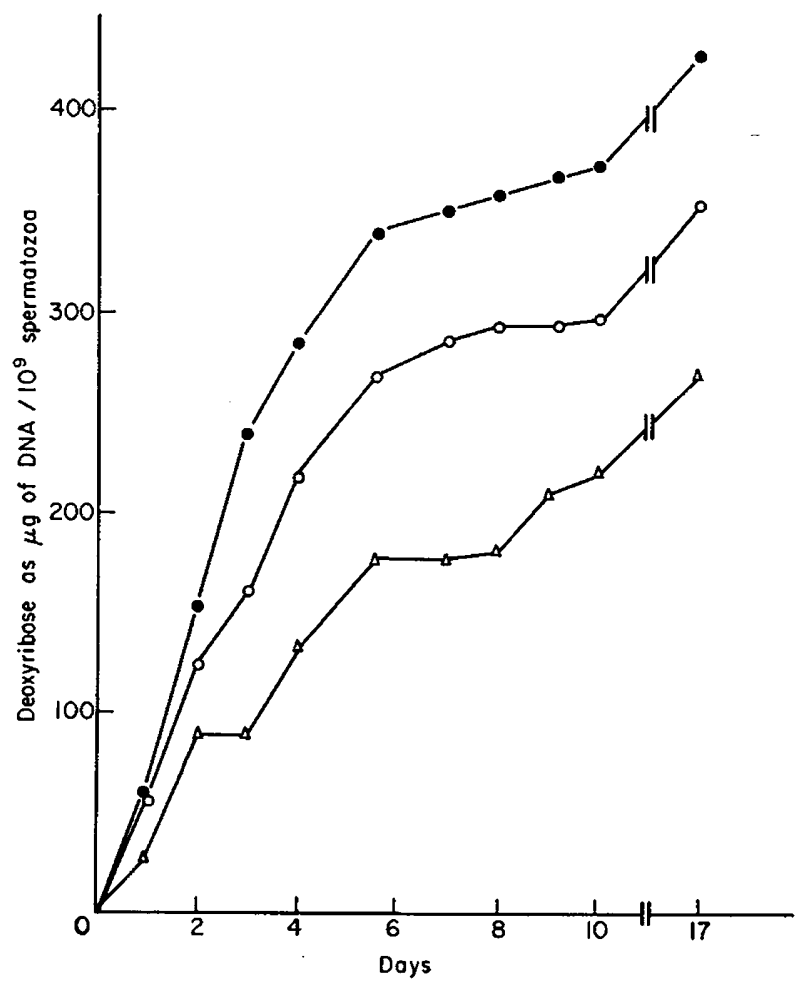

TEXT-FIG. 2. Loss of deoxyribose from cold-shocked and frozen ram spermatozoa during incubation at $37^{\circ} \mathrm{C}$. Each point represents the mean of three replicates. 9 , Frozen; $O$, cold-shocked; $\Delta$, control.

than the control and the loss was even greater from frozen cells. During subsequent dialysis the rate of loss of deoxyribose was similar for all treatments.

\section{DISCUSSION}

Washing ram spermatozoa mildly in isotonic buffer did not cause any significant loss of DNA, protein or phospholipids in the present study, although similar washing in Ringer is reported to remove about $10 \%$ of the plasmalogen (Hartree \& Mann, 1959). The high acid-soluble phosphorus content of whole ram semen is due to glycerylphosphorylcholine (Dawson, Mann \& White, 1957) at least some of which is associated with the spermatozoa and is lost on washing. The presence of contaminating seminal plasma would not account for the difference observed.

Extracting ram spermatozoa twice with $10 \% \mathrm{NaCl}$ removes about $10 \%$ of the non-dialysable orcinol- and biuret-reactive material and phosphorus from the spermatozoa. The resistance of the DNA of mammalian spermatozoa to 
extraction with concentrated salt solutions is well known (see Mann, 1964) and the small amount of diphenylamine-reactive material found in the $10 \% \mathrm{NaCl}$ washings probably arises from contaminating spermatozoa. Other workers have also found loss of phospholipid and protein from ram and bull spermatozoa on cold shock or freezing (Mann \& Lutwak-Mann, 1955; Blackshaw \& Salisbury, 1957; Hartree \& Mann, 1959; Pickett \& Komarek, 1964) but loss of polysaccharide has apparently not been previously reported. All three components are present in the acrosome (Hartree \& Srivastava, 1965) which can be loosened and even completely detached by cold treatment (Hancock, 1952; Iype et al., 1963). Freezing tended to cause a greater loss of protein, nondialysable phosphorus and polysaccharide from the spermatozoa than did cold shock. Both forms of cold treatment rendered high molecular weight components soluble and extractable. It seems probable that these components might be lost particularly from the acrosomal region of the cell.

Although there was no loss of DNA from cold-shocked or frozen ram spermatozoa during a 30-min incubation period, loss of DNA occurred when the spermatozoa were incubated for $6 \mathrm{hr}$ at $37^{\circ} \mathrm{C}$. The longer incubation required to demonstrate loss of DNA from ram spermatozoa may be due to the action of deoxyribonucleases. A highly active DNase $I$ is present in ram seminal plasma and this enzyme passes into the spermatozoa on freezing (Quinn, 1968). Loss of DNA from bull and boar spermatozoa aged in vitro has previously been reported (Segina \& Norman, 1964; Anand, Hoekstra \& First, 1967). Degradation of DNA into dialysable fragments occurs slowly in senescent ram semen (Textfig. 2) but the process is accelerated if the semen has been cold-shocked or frozen.

The present observations confirm that the most spectacular effect of cold shock and freezing is on the acrosome of susceptible spermatozoa (Hancock, 1952; Walton, 1957; Iype et al., 1963). We have, however, shown that in ram spermatozoa the effect is region specific, i.e. confined to the corrugated and apical regions but not smooth regions, and that it is not so much a loosening of the acrosome in our material (the juxtanuclear part of the acrosomal membrane remains in place) as a swelling. It is not possible to be sure from electron microscopic observations that the swelling observed is by itself associated with any loss of acrosomal material. The blebbing of the acrosomal membrane so frequently observed would, however, very likely be associated with such a loss. The reality of the loss is not, of course, in question-the chemical determinations on the loss of orcinol-reactive material are quite definitive.

It is difficult to see how a change in the acrosome of this nature could cause such profound changes in the distant motor apparatus. Our studies of the latter have been unrewarding. The tail filaments and fibrils show no detectable change in either cold-shocked or frozen spermatozoa. The only change detected has been a loss of material, relatively small in the case of cold shock and probably mostly protein in nature, from the mitochondrial sheath of the middle piece. It is not even clear whether this loss of material could be a cause of the functional changes induced in the spermatozoon by cold shock and freezing. If the histochemical results are accepted at face value (neglecting the technical qualification made in the appropriate section) the loss of protein from the 
middle piece caused by cold-shocking in seminal plasma is no greater than that caused by mere washing of the spermatozoa in Ringer.

Despite the apparent lack of effect of cold-shocking or freezing on the plasma membrane covering the 'functional' parts of the spermatozoon it seems likely that the effects of these treatments depend principally on a change in membrane permeability. Such a permeability change seems likely to be fairly profound and general, since it results not only in a loss of cations (Blackshaw \& Salisbury, 1957; Quinn \& White, 1966) but also in the loss of protein from mitochondria in the middle piece where the protein is separated from the exterior by three membranes-the plasma membrane and the double membrane surrounding the mitochondrion itself. That there is no apparent loss of protein from the motor filaments or the fibrous sheath of the principal piece may merely reflect the insolubility of the proteins at these sites.

\section{ACKNOWLEDGMENTS}

The authors are indebted to Professor C. W. Emmens for his interest and advice and to the Ford Foundation and the Australian Wool Board for financial assistance. One of us (P.J.Q.) was supported by a Royal Agricultural Society (N.S.W.) Fellowship.

\section{REFERENCES}

ANAND, A. S., Hoekstra, W. G. \& First, N. L. (1967) Effect of ageing of boar spermatozoa on cellular loss of DNA. F. Anim. Sci. 26, 171.

Blackshaw, A. W. (1954) A bipolar rectal electrode for the production of ejaculation in sheep. Aust. vet. $\mathcal{F} .30,249$.

BLAckshaW, A. W. (1958) The effects of incubation temperature and cold shock on the metabolism of ram spermatozoa. Aust. F. biol. Sci. 11, 581.

Blackshaw, A. W. \& Salisbury, G. W. (1957) Factors influencing metabolic activity of bull spermatozoa. II. Cold shock and its prevention. F. Dairy Sci. 40, 1099.

Burton, K. (1956) A study of the conditions and the mechanism of the diphenylamine reaction for the colorimetric estimation of deoxyribonucleic acid. Biochem. 7. 62, 315.

Clelland, K. W. (1965) Sources of error in two-wavelength microspectrophotometry. Aust. F. biol. Sci. $18,1057$.

Dawson, R. M. C., ManN, T. \& Whrte, I. G. (1957) Glycerylphosphoryl choline and phosphorylcholine in semen, and their relation to choline. Biochem. $\mathcal{F} .65,627$.

Emmens, C. W. (1947) The motility and viability of rabbit spermatozoa at different hydrogen-ion concentrations. F. Physiol., Lond. 106, 471.

Fiske, C. H. \& SubBa Row, Y. (1925) The colorimetric estimation of phosphorus. 7. biol. Chem. 66, 375 .

Grles, K. W. \& Myers, A. (1965) An improved diphenylamine method for the estimation of deoxyribonucleic acid. Nature, Lond. 206, 92.

Hancock, J. L. (1951) A staining technique for the study of temperature shock in semen. Nature, Lond. $167,323$.

Hancock, J. L. (1952) The morphology of bull spermatozoa. F. exp. Biol. 29, 445.

Hartree, E. F. \& ManN, T. (1959) Plasmalogen in ram semen, and its role in sperm metabolism. Biochem. F. 71, 423.

Hartree, E. F. \& Srivastava, P. N. (1965) Chemical composition of the acrosomes of ram spermatozoa. 7. Reprod. Fert. 9, 47.

HewrtT, L. F. (1937) Separation of serum albumin into two fractions. II. Observations of the glycoprotein fraction. Biochem. 7. 37, 360.

Iype, P. T., Abraham, K. A. \& Bhargava, P. M. (1963) Further evidence for a positive role of acrosome in the uptake of labelled amino acids by bovine and avian spermatozoa. F. Reprod. Fert. 5, 151.

LAsley, J. F., Easley, G. T. \& MaKenzie, F. F. (1942) A staining method for the differentiation of 
live and dead spermatozoa. I. Applicability to the staining of ram spermatozoa. Anat. Rec. 82 167.

MANN, T. (1964) The biochemistry of semen and of the male reproductive tract, 2nd edn. Methuen, London.

MANN, T. \& LUTWAK-MANN, G. (1955) Biochemical changes underlying the phenomenon of cold shock in spermatozoa. Archs sci. biol., St. Pétersb. 39, 578.

MAYer, D. T. (1955) The chemistry and certain aspects of the metabolic activities of mammalian spermatozoa. Mich. Univ. Cent. Symp. on Reprod. E Infertil., p. 45. Michigan State University, East Lansing.

Pickett, B. W. \& Komarex, R. J. (1964) Evidence for loss of lipid from bovine spermatozoa due to freezing. 7. Dairy Sci. 47, 905.

Quinn, P. J. (1968) Deoxyribonuclease activity in semen. F. Reprod. Fert. 17, 35.

Quinn, P. J., Salamon, S. \& White, I. G. (1968) The effect of cold shock and deep-freezing on ram spermatozoa collected by electrical ejaculation and by an artificial vagina. Aust. F. agric. Res. 19, 119.

Quinn, P. J. \& White, I. G. (1966) The effect of cold shock and deep-freezing on the concentration of major cations in spermatozoa. F. Reprod. Fert. 12, 263.

Quinn, P. J., White, I. G. \& WirRIck, B. R. (1965) Studies of the distribution of the major cations in semen and male accessory secretions. J. Reprod. Fert. 10, 379.

Segina, M. R. \& Norman, C. (1964) Age-related changes in the DNA of bovine sperm. Proc. Vth int. Congr. Anim. Reprod. A.I., Trento, 4, 276.

Umbreit, W. W., Burris, R. H. \& STAUfFer, J. F. (1959) Manometric techniques in tissue metabolism. Burgess, Minneapolis.

Wales, R. G., ScotT, T. W. \& White, I. G. (1961) Biuret reactive materials in semen. Aust. F. exp. Biol. med. Sci. 39, 455.

Walton, A. (1957) Cold shock of spermatozoa. Proc. R. Soc. B, 147, 508.

White, I. G., Blackshaw, A. W. \& Emmens, C. W. (1954) Metabolic and motility studies relating to the low temperature storage of ram and bull spermatozoa. Aust. vet. $\mathcal{F} .30,84$. 